\title{
Illicit International Traffic in Antiquities
}

If scientific archaeology has any meaning, the value of museum objects for scholarship is closely tied to full knowledge of their origin, history, and context. Archaeological fieldwork has become a recognized scientific methodology only as it has moved from being a bundle of treasure-hunting and preservative techniques to being a systematic attempt to place the findings of excavations in a spatial, temporal, and functional framework of maximal accuracy.

International traffic in antiquities runs in a diametrically opposite direction. Because it is illegal in virtually all countries of origin, context tends to be concealed even where it is known. With surreptitious digging, a proper understanding of context is, of course, seldom known to anyone except in the grossest terms. Qualified aesthetic judgements undoubtedly contribute something to the prices attached to objects that move in such trade. However, those judgements are inextricably intertwined with ethnocentric considerations, with fads that follow an internal dynamic of their own, with the search for hedges against inflation, and with the complex role of status symbols presumably reflecting taste and affluence. Purely as an abstract question, few of us would deny that for professional archaeologists to be associated with trafficking in antiquities would be to negate the scientific basis of our own profession.

Contradictions in principle may mean little if the practical outcome is on the whole a positive one. Within U.S. archaeology, private collectors and professionals main tain variable but on the whole symbiotic relations, in which at least some of the needs of both are satisfied. Individual sites still are all too frequently gutted and their objects irretrievably lost to science, but on the whole there is an increasingly wide, informal pooling of knowledge. More and more amateur excavators have had at least some academic training, keep careful records of their work, and disseminate their findings through meetings of local or regional societies as well as publications. Thus, nonprofessional work speeds and amplifies professional research in significant ways, particularly with regard to ranges of distribution and typological variation.

The situation is fundamentally different if we turn to the illicit traffic originating in other countries. Scientific archaeologists, excavating on behalf of U.S. or other academic institutions and museums, in essentially all cases are carefully regulated by law. The antiquities trade flourishes either on the fringes of the law or, in most cases, in blatant disregard of it. Its methods of acquisition and "export" depend on the systematic suborning of local officials. The mark-up has become so huge between the selling price of objects in countries like the U.S. and what the original, illicit digger receives that the funds available for this bribery make civil services in most less affluent countries simply powerless to deal with it. National treasures thus are seen to flow from the impoverished to the affluent, with the former being incapable of retaining even some of the most important and valuable symbols of their own cultural heritage. Small wonder that suspicion of and hostility to the entire process of excavating and collecting has taken root in most of the world. And those who bear the brunt of the new and ominously growing at titudes can only be the professional archaeologists who must work within a framework of official regulation and approval.

It must further be stressed that the rapid growth of the international traffic is making this situation progressively worse. While there is much variation from country to country, in general the scale of looting has mounted alarmingly in recent years. Turkey, to cite one example, has felt compelled to lodge formal protests over the policies of some American art museums in purchasing and highly publicizing objects stolen there by dealers. The effect of popular and of ficial indignation on reputable American archaeologists working in Turkey is still unclear at this writing, but all accounts indicate that future scientific programs have been seriously jeopardized. Mexico and Guatemala are examples falling within the field of more readers of this journal, and here we are fortunate in being able to cite an authoritative (and already incomplete) listing of "recently stolen" antiquities: Clemency Coggins, "Illicit traffic of Pre-Columbian Antiquities," Art Journal 29 (Fall, 1969). Editorial consent could not be obtained for the published form of this article to include the present whereabouts of the objects in question, but the list includes many of the most prestigious U.S. art museums. 
A variety of moves have been adopted or proposed to counteract this traffic. At the international level, a draft convention has been placed before the UNESCO General Conference that would pledge signatory countries to specific measures. Among other provisions, each subscribing country would promise measures to prevent the import of illegally obtained antiquities by museums and other institutions, "consistent with national legislation." The practical meaning of this last proviso in the U.S. is, of course, that the convention would apply directly only to Government bodies while its effect on private museums would be that of ethical example. Bilateral agreements in some cases may be an effective alternative. Recently one such treaty has been signed by the U.S. and Mexico, and now awaits action by both Senates. It commits the U.S. Attorney General to take judicial action under laws applying to stolen property for the recovery and return to Mexico of illegally removed objects "of outstanding importance." In the long run, however, the obvious limitations to these documents suggest that the key to the problem lies closer to home. No agreements with real teeth will be signed, and the traffic will not be controlled, until and unless private museums and collectors here are put on public notice that what they are doing is destructive to international understanding and to scholarship.

Again, there have been proposed a variety of approaches to this task of publicizing the issue and winning public opinion. Through a variety of open appeals, the Internal Revenue Service might be induced to refuse approval of charitable donations of antiquities to museums as tax deductions without proof of legal export from their country of origin. Some legal opinion indicates that law suits are possible, either to return particularly notorious thefts to their country of origin or to proceed against museums whose systematic participation in the traffic is a long-term, particularly flagrant breach of their public trust. With wide publicity and an effective approach to Congress, it is not impossible that the U.S. will eventually become a signatory to an international antiquities code that labeled certain cases of archaeological looting as theft and undertook to prosecute knowing private purchasers of the stolen goods. The legality and technical feasibility of these and other steps is not a question that can be discussed here. But what does seem clear is that only a massive, organized effort to realign public opinion against this looting-and, if necessary, against institutions that sanction it and participate in it through their purchases-will make any effective measures possible.

Who has greater responsibility to initiate and support such a broad, multi-faceted, and obviously long-range campaign than a society devoted to the interests of American archaeology and American archaeologists? If we do nothing, we condone these growing outrages by our silence and jeopardize the international progress of our field.

ROBERT McC. ADAMS

Division of the Social Sciences The University of Chicago 


\section{World Archaeology}

Executive Editor DEREK ROE

Editorial Board Martin Biddle Barry Cunliffe Henry Hodges Roy Hodson Ian Longworth Colin Platt Bernard Wailes
This new journal has become required reading for professional archaeologists. Deliberately flexible in approach, it synthesizes the best contemporary thought on matters of common interest to archaeologists throughout the world.

The June 1971 issue (Volume III No I) will be on 'Technological Innovation' and further issues are planned on the themes of 'Archaeology and Ethnography', 'Social Structures', 'Art and Design' and 'Cultural Survival'.

Subscriptions (three issues a year) $\$ 11$ to Routledge \& Kegan Paul, Broadway House, Reading Road, Henley-on-Thames, Oxon, England. 